\title{
Venetoclax alkalmazása myeloma multiplexben
}

\author{
Szita Virág Réka ${ }^{\circledR}$, Varga Gergely \\ Semmelweis Egyetem, Belgyógyászati és Hematológiai Klinika, Budapest
}

\begin{abstract}
Bár az elmúlt évtizedben számos új gyógyszer került be a myeloma multiplex kezelésének eszköztárába, a betegség az esetek nagy részében továbbra is gyógyíthatatlan, ezért új hatóanyagok bevonására van szükség. A venetoclax a bcl-2 antiapoptotikus fehérje gátlása révén ható új típusú gyógyszermolekula, amelynek különböző hematológiai malignitásokban történő alkalmazásáról az elmúlt években számos tanulmány készült. Myeloma multiplexben való alkalmazása a hatásmechanizmusnak megfelelően a magas bcl-2/mcl-1, illetve bcl-2/bcl-xl aránnyal rendelkező betegeknél előnyös, amely kedvező konstelláció elsősorban a $\mathrm{t}(11 ; 14)$ transzlokált betegeknél áll fenn. Bár korai tanulmányok mutattak kedvező eredményeket más citogenetikai eltéréssel rendelkező betegeknél is, a törzskönyvezési igénnyel indított nagy, randomizált 3. fázisú Bellini klinikai vizsgálat a venetoclaxszal kezelt betegeknél ugyan a t(11;14) csoportban nagyon kedvező eredményekre vezetett, de a nem $\mathrm{t}(11 ; 14)$ betegeknél többlethalálozást és OS-csökkenést mutatott ki. A vizsgálati eredmények értelmében a venetoclax-alapú terápia myeloma multiplexben csak $\mathrm{t}(11 ; 14)$ betegeknek ajánlható. Az optimális alkalmazással és kombinációs partnerekkel kapcsolatban további vizsgálatok szükségesek, mindazonáltal a venetoclax terápia a myeloma multiplex személyre szabott kezelésének irányába tett első lépést jelentheti.
\end{abstract}

Kulcsszavak: $\mathrm{t}(11 ; 14)$, venetoclax, bcl-2

\section{The use of venetoclax in multiple myeloma}

\begin{abstract}
Although recent decades introduced several new drugs to multiple myeloma therapy, the disease is still considered incurable in most cases and thus warrants the development of new agents. Venetoclax is a novel type of drug inhibiting the antiapoptotic bcl-2 molecule whose use in varying hematological malignancies has been evaluated by a multitude of studies in recent years. Considering its mechanism of action, application in multiple myeloma is possible in patients with high bcl-2/mcl-1 and bcl-2/bcl-xl ratios. This favourable constellation is primarily found in patients with $\mathrm{t}(11 ; 14)$ translocations. Although early studies showed some promising results in patients with different citogenetic makeup, the large randomized phase 3 Bellini study which confirmed ventetoclax's high effectivity in $\mathrm{t}(11 ; 14)$ patients, proved increased mortality and OS loss in the case of non-t $(11 ; 14)$ patients treated with the drug. In light of these results, venetoclax based therapy may only be recommended for $t(11 ; 14)$ myeloma patients. Further research is needed to determine optimal application and combination partners, but venetoclax therapy may be the first step towards personalized myeloma care.
\end{abstract}

Keywords: t(11;14), venetoclax, bcl-2

(Beérkezett: 2021. január 26.; elfogadva: 2021. február 26.)

\begin{abstract}
Rövidítések
AML - akut mieloid leukémia; AL amyloidosis - amyloid light chain amyloidosis; CLL - krónikus limfoid leukémia; DLBCL diffúz nagy B-sejtes limfóma; ER - endoplazmatikus retikulum; FDA - Food and Drug Administration; G-CSF - granulocytastimuláló faktor; IMID - immunomodulatory imide drug; MM - myeloma multiplex; MOMP mitochondrial outer membrane permeabilization, mitochondrium külső membránpermeabili-
\end{abstract}

záció; NEAK - Nemzeti Egészségbiztosítási Alapkezelő; NHL - non-Hodgkin-limfóma; OGYÉI - Országos Gyógyszerészeti és Élelmezés-egészségügyi Intézet; ORR - overall response rate, teljes válaszarány; PCL - plazmasejtes leukémia; PFS - progression free survival, progressziómentes túlélés; RT/PCR - reverse transcription polymerase chain reaction; VTD - bortezomib thalidomid dexamethason; UPR - unfolded protein response, félrehajtogatott fehérjereakció; UPS - ubiquitin-proteasoma rendszer

\footnotetext{
@ Levelezési cím: Dr. Szita Virág Réka, Semmelweis Egyetem Belgyógyászati és Hematológiai Klinika, 1088 Budapest, Szentkirályi u. 46.; Tel.: +36-20-670-1242; E-mail: virag.szita@gmail.com
} 
A mitokondriális apoptotikus apparátus befolyásolása révén ható venetoclax alkalmazását több hematológiai malignitás (AML, relabált/refrakter NHL, illetve CLL) esetén vizsgálták, az utóbbi indikációban rituximabbal, majd obinutuzumabbal kombinálva 2020. május 1-tôl a tételes rendszeren belül rendelhetővé vált Magyarországon is, ilyen módon gyưlik a hazai tapasztalat a gyógyszerrel kapcsolatban. Ugyanakkor myeloma multiplexben (MM) való alkalmazása a különböző citogenetikai alcsoportokban észlelt eltérő válaszok, illetve a kezdeti ígéretes eredményeket követő riasztó halálozási adatok miatt nem magától értetődő. Összefoglalónkban ezért az ezzel kapcsolatos eddigi ismereteinkről szeretnénk áttekintést adni.

\section{Hatásmechanizmus}

$\mathrm{Az}$ egészséges plazmasejtekre és myelomasejtekre egyaránt jellemző immunglobulinszekréció a fokozott fehérjetermeléssel párhuzamosan a hibás, félrehajtogatott fehérjék mennyiségének növekedésével is jár [1]. A leggyakrabban használt myelomaellenes gyógyszerek (proteasomainhibitorok, IMID-ek) fooként a nagymértékü fehérjeszintézis nyomán létrejövő sejtélettani folyamatokat célozzák [1-3], míg a venetoclax egy ehhez kapcsolódó rendszer, az apoptotikus apparátus befolyásolása révén fejti ki hatását.

$\mathrm{Az}$ immunglobulinszintézis melléktermékeként létrejövő hibás fehérjék a UPR (unfolded protein response, fél- rehajtogatott fehérjereakció) bekapcsolása révén olyan folyamatokat indítanak el, amelyek révén a sejt első lépésben megkísérli a hibás fehérjék szintjét kordában tartani, és a chaperonok szintjének növelése révén a fehérjehajtogatást helyrehozni [2, 4] (1. ábra). A UPR során aktiválódik az ubiquitin-proteaszóma rendszer (UPS), és nő a proteindegradáció, az ER expandál [5]. Amennyiben ezek a megküzdési folyamatok sikertelenek maradnak, és a félrehajtogatott fehérjék szintje meghaladja a lebontókapacitást, akkor az ER-t túlterhelik a hibás fehérjék, a UPR pedig elindítja az apoptózist [5] (2. ábra).

A legtöbb sejtélettani folyamathoz hasonlóan az apoptotikus apparátus szabályozása is összetett, több lépcsőben szabályozott folyamat. A szabályozást a Bcl-2 családba tartozó mitokondriális fehérjék végzik. Az apoptózis akkor indulhat el, ha a mitokondriális membránban található effektorok (Bak, Bax) oligomerizációja egy csatornát képez. A MOMP (mitochondrial outer membrane permeabilization - mitokondrium külső membránpermeabilizáció) révén a mitokondrium membránjai között tárolt fehérjék és a citokróm c kiszabadulnak, és a kaszpázrendszer aktiválódik. A MOMP létrejöttét a Bcl-2 család aktivátor (Bid, Bim, Puma), antiapoptotikus (Mcl-1, Bcl-2, Bcl-xl etc.) és szenzitizátor (Noxa, Bad, Bik) tagjai szabályozzák. Az apoptózis extrinsic (Fas-ligand-aktiválás, kaszpázkaszkád) vagy intrinsic (DNS-károsodás, ER stressz) útjának aktiválása az aktivátor, antiapoptotikus és szenzitizátor fehérjék egyensúlyának megbontásával indukál apoptózist.

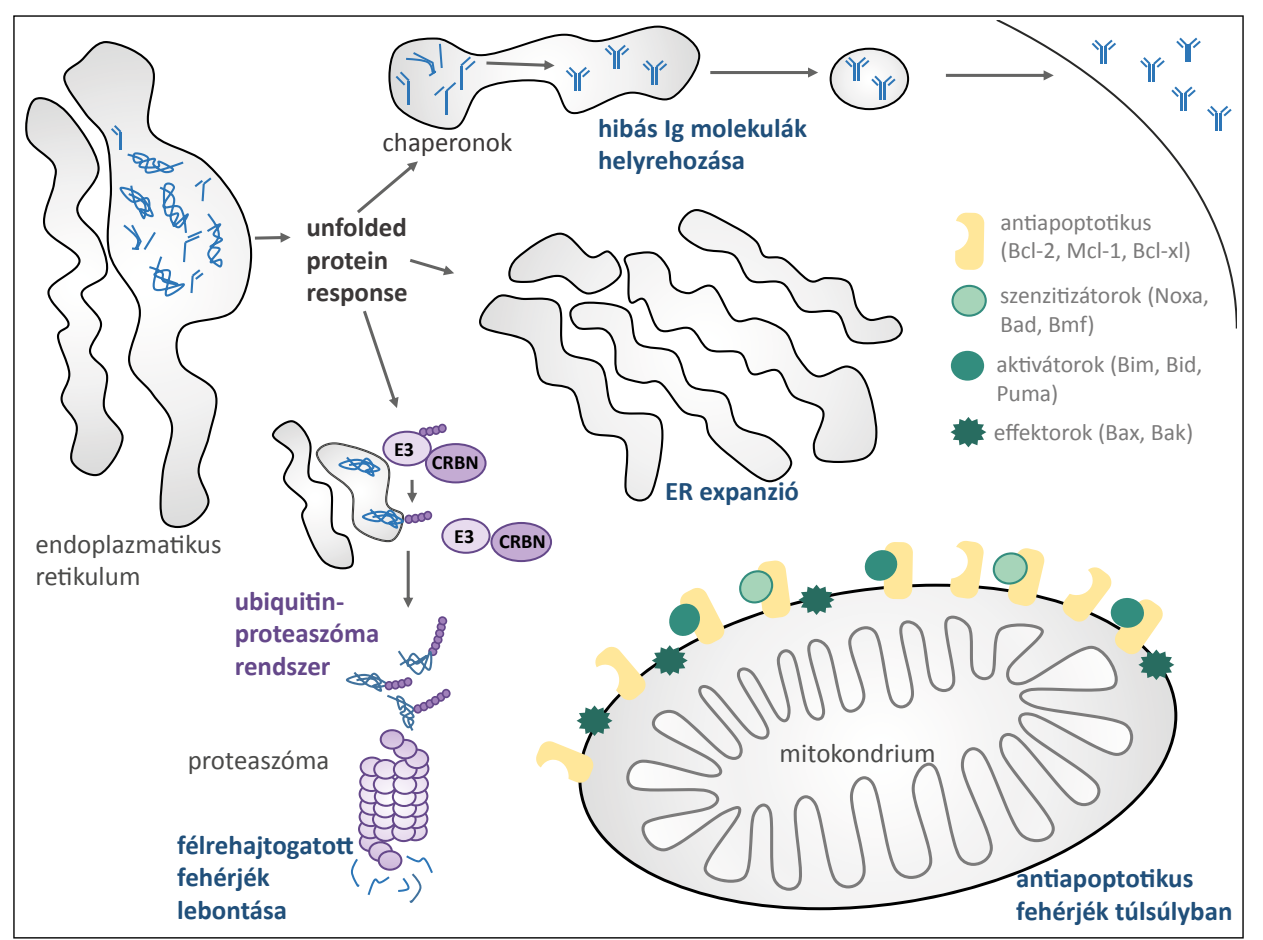

1. ábra. Kezeletlen myelomasejt. A fokozott Ig-szekréció miatt nagy számban létrejövő hibás, hajtogatatlan fehérjék beindítják az UPR-t, ami több megküzdési stratégia révén egyensúlyban tartja a sejt homeosztázisát. A nagy számban jelen lévő antiapoptotikus fehérjék megkötik az aktivátorokat és szenzitizátorokat, így az apoptózis nem tud elindulni

(E3-CRBN - E3-ligáz-Cereblon komplex; ER - endoplazmaticus reticulum) 


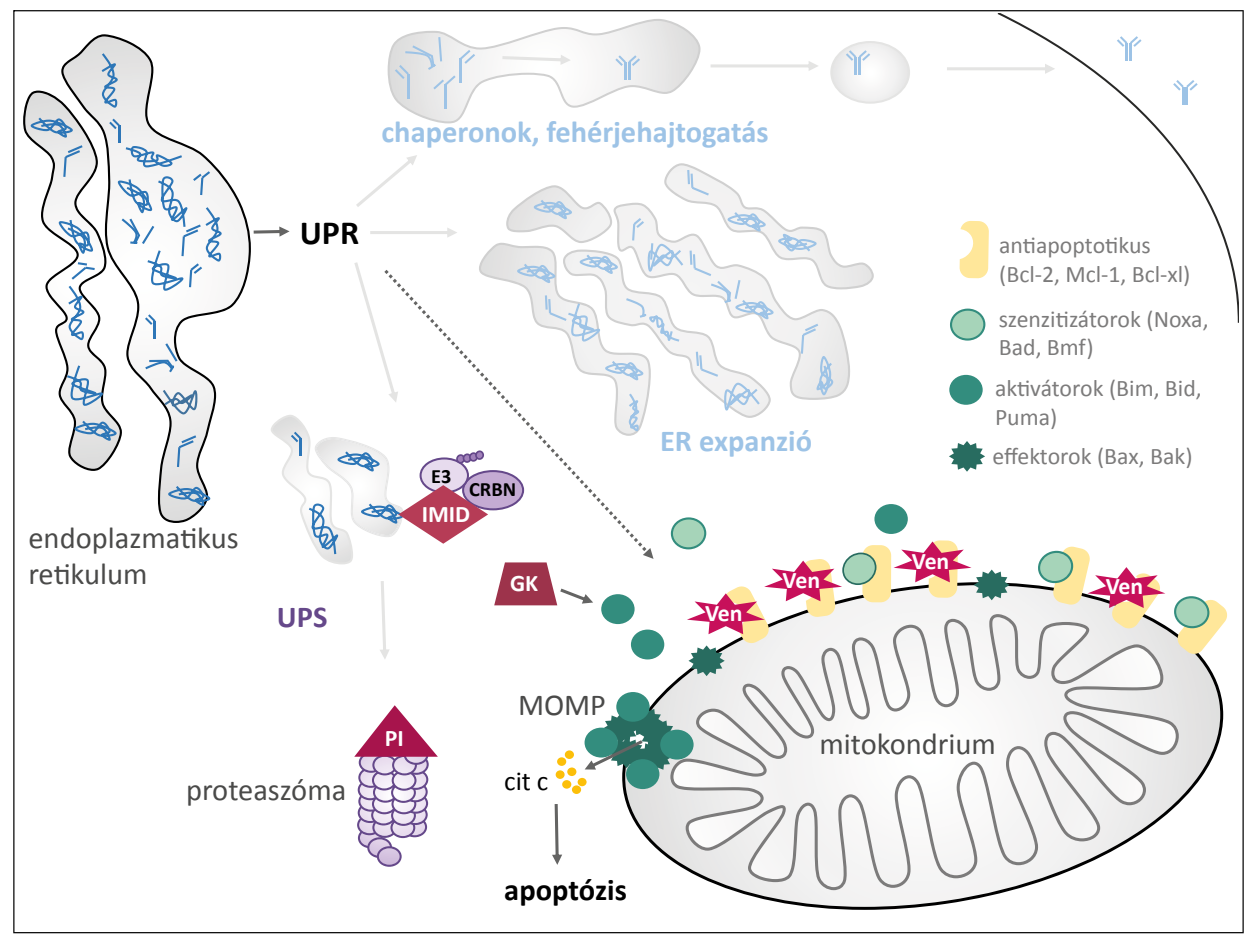

2. ábra. Myelomasejt a kezelés során. A kombinált kezelés (proteaszómainhibitorok, IMID-ek, glukokortikoidok) révén a myelomasejt hajtogatatlan fehérjékkel való megküzdési lehetőségei kimerülnek, az UPR az apoptosis felé tereli a sejtet a szenzitizátor molekulák szintjének emelésével. A venetoclax által lefoglalt antiapoptotikus bcl-2 fehérjék nem tudnak szenzitizátorokat és aktivátorokat megkötni. Ha más antiapoptotikus fehérje nem áll rendelkezésre, az aktivátorok és effektorok komplexet képezve membráncsatornát hoznak létre (MOMP), és a kiszabaduló citokróm c elindítja az apoptózist (cit c - citokróm c; E3-CRBN - E3-ligáz-Cereblon komplex; GK - glukokortikoid; MOMP - mitochondrial outer membrane permeabilization - mitochondrium külső membránpermeabilizáció; PI - proteasomainhibitor; UPR - unfolded protein response - hajtogatatlanfehérje-válasz; UPS - ubiquitin-proteasome system ubiquitin-proteaszóma rendszer; Ven - venetoclax)

A proteaszómainhibitorok és IMID-ek által gátolt ubiquitin-proteaszóma rendszer és csökkent fehérjedegradáció a hibás fehérjék felszaporodása révén a UPR olyan mértékű aktiválódásához vezet, ami képes az apoptotikus apparátust és a $\mathrm{Bcl}-2$ család fehérjéit az apoptózishoz szükséges mértékben felborítani $[1,3]$. Azonban a daganatsejtek ez ellen képesek az antiapoptotikus fehérjék túltermelésével védekezni, ami a daganatsejtek fokozottabb túléléséhez és terápiarezisztencia kialakulásához vezet.

A venetoclax a szenzitizátor fehérjékhez hasonló hatású molekula, ami az antiapoptotikus Bcl-2 megkötésével szabad utat ad az aktivátorok és szenzitizátorok által serkentett MOMP képződés számára. Megjegyzendő azonban, hogy a venetoclax kizárólag a Bcl-2 fehérjéhez kötődik, ezért csak abban az esetben számíthatunk jó klinikai hatásfokra, ha a sejt az antiapoptotikus hatás elérésében elsősorban a Bcl-2-re támaszkodik. Amennyiben a plazmasejtben nagyobb mennyiségben elérhető más $\mathrm{Bcl}-2$ családba tartozó antiapoptotikus fehérje (Mcl-1 vagy Bcl-xl), akkor nem számíthatunk érdemi venetoclaxhatásra, hiszen ezek a fehérjék továbbra is védik a sejtet az apoptózistól. Az antiapoptotikus család minden tagjához kötődő nem szelektív kísérleti molekula, a navitoclax a klinikai alkalmazhatóságot korlátozó mértékủ thrombocytopeniát okozott (ezért elsősorban a Bcl-xl gátlása felelős).

\section{Klinikai vizsgálatok}

Már egyes preklinikai tanulmányok is előrevetítették, hogy a venetoclaxterápia hatásosabb lehet $\mathrm{t}(11 ; 14)$ esetén [6], hiszen ez a genetikai eltérés jól korrelál a magasabb Bcl-2- (és alacsony Mcl-1- és Bcl-xl-) szintekkel. Egy venetoclaxot placebóval összehasonlító 1. fázisú klinikai vizsgálatban [7] a 66 bevont relabált/refrakter myelomás beteg $45 \%$-a rendelkezett $(11 ; 14)$ transzlokációval, esetükben az ORR $40 \%$ volt - ezzel szemben a nem $\mathrm{t}(11 ; 14)$ csoportba sorolt betegek közül csupán kettő reagált, egyikük esetén a 14 kromoszóma transzlokációs partnerét nem azonosították, míg a másiknál a citogenetikai adat hiányzott. A preklinikai adatok szerint előnyös lehet a venetoclax bortezomibbal és szteroiddal való kombinációja, egy ezt vizsgáló fázis 1 vizsgálatban [8] citogenetikai eltéréstől függetlenül kedvező, $68 \%$-os válaszarányt találtak. Fontos megjegyezni azonban, hogy ezekben a korai tanulmányokban a venetoclax biztonságossági profiljának értékelésére a betegek egy része ( $\mathrm{kb}$. negyede [7], illetve több mint fele [8]) a hatásosnak tartott kb. 800 mg-os napi dózisnál kevesebb venetoclaxot kapott, illetve a vizsgálatok kontrollcsoport nélkül történtek.

Ezzel szemben a BELLINI (M14-031) nyílt, randomizált 3. fázisú vizsgálatban myeloma multiplexes betegek 
1-3 megelőző kezelési vonalat követően randomizálva kaptak bortezomib-dexamethason kombináció mellé - a korábbi tanulmányok alapján biztonságosnak és hatásosnak ítélt dózisú, napi $800 \mathrm{mg}$ - venetoclaxot, illetve placebót kettős vak módon. A myeloma szempontjából ígéretes eredmények ellenére (PFS 22,4 vs. 11,5 hónap, ORR $81 \%$ vs. $68 \%$ a venetoclaxot vs. a placebót kapó betegek esetében) az interimvizsgálat alarmírozó különbségre hívta fel a figyelmet: a venetoclaxot szedő betegek halálozása kétszerese volt a kontrollcsoporténak (21,1\% vs. $11,3 \%$ ), ami miatt az FDA (Food and Drug Administration) az összes venetoclaxot vizsgáló klinikai vizsgálatot átmenetileg felfüggesztette [9], és a többlethalálozás okának tisztázására alcsoport-analízis történt. Fontos megjegyezni, hogy ebben a klinikai vizsgálatban vegyes citogenetikai eltérésekkel rendelkező betegek vettek részt, $\mathrm{t}(11 ; 14)$ transzlokációja mindössze a betegek 12\%-ának volt. A Bcl-2-szintet kvantitatív RT/PCR-ral mérve a betegek meglepően magas aránya, több mint $80 \%$-a mutatott magas Bcl-2-génexpressziót; a többi antiapoptotikus fehérje szintjét ( $\mathrm{Bcl}-2 / \mathrm{Mcl}-1, \mathrm{Bcl}-2 / \mathrm{Bcl}-\mathrm{xl}$ arányt) viszont ebben az elemzésben nem vizsgálták. A magas Bcl-2expressziójú és/vagy $(11 ; 14)$ transzlokált betegek a venetoclaxkezelésre jobban reagáltak, míg ezzel szemben a legrosszabb túlélést a venetoclaxot kapó, magas citogenetikai rizikójú és alacsony $\mathrm{Bcl}$-2-expressziójú betegek körében észlelték. A várakozásnak megfelelően a legjobban a $\mathrm{t}(11 ; 14)$ betegek reagáltak a venetoclaxkezelésre, az eddigi publikációk szerint ebben a csoportban sem a medián PFS-t, sem a medián OS-t nem érték még el, szemben a kontrollcsoport 9,9 hónapos PFS-ével. Nem egyértelmü ezzel szemben, hogy pontosan mi állhat a többlethalálozás hátterében [10], magyarázatként a megnövekedett infekciós kockázat merült fel elsősorban, de fontos kiemelni, hogy a többlethalálozás nem a venetoclaxot kapó $\mathrm{t}(11 ; 14)$ betegek között volt észlelhető. Ezen adatok fényében az FDA a $\mathrm{t}(11 ; 14)$ alcsoportban engedélyezte a venetoclax hatásosságának vizsgálatát [11].

\section{Kombinációs partnerek}

A myelomaellenes gyógyszerek fentebb részletezett hatásmechanizmusából következhet, hogy más gyógyszerekhez hasonlóan a venetoclaxnak is vannak olyan kombinációs partnerei, amelyek együtt adásával szinergista hatást érhetünk el.

A myelomás betegek kezelése során általánosan alkalmazott szteroid (dexamethason) in vitro vizsgálatokban kedvezően befolyásolta a proapoptotikus fehérjék (pl. a Bim) expresszióját, és megtöbbszörözte a venetoclax hatását. Ezt a hatást legjobban úgy modellezhetjük, hogy szteroid adását követően a Bcl-2 molekulák propapoptotikus Bim fehérjével „töltötté” válnak, a venetoclax pedig az ily módon „töltött” Bcl-2 molekulákról sokkal több apoptotikus fehérjét képes felszabadítani. Hasonlóképpen a carfilzomib vagy bortezomib alkalmazásakor mért ma- gasabb Noxaszint és következményes Mcl-1-szint-csökkenés is a Bcl-2-függőség és venetoclaxérzékenység irányába hat. A proteaszómagátlás miatt megnövekedett ER stressz és fokozott UPR könnyebben beindíthatja a myelomás sejtek apoptózisát, ha a sejt a venetoclax által „érzékenyített" állapotban van. Ez is indokolhatja, hogy az eddig végzett klinikai vizsgálatokban elsősorban a bortezomib-venetoclax kombinációt tesztelték. Alacsony betegszámú esetleírások alapján relabált/refrakter myelomás, $\mathrm{t}(11 ; 14)$ betegeknél carfilzomib-venetoclax kombinációval meglepően jó válaszarányt értek el [12, 13], de esettanulmányban beszámoltak daratumumabbal való sikeres együtt adásról is [14]. Az elméleti megfontolások mellett természetesen a randomizált klinikai vizsgálatokban mért hatásosság a perdöntő. Jelenleg hazánkban is zajlik a carfilzomib-venetoclax kombinációt vizsgáló nemzetközi multicentrikus klinikai tanulmány.

\section{Célcsoport}

Ahogy azt a fentiekben részleteztük, a kedvező venetoclaxhatáshoz az antiapoptotikus fehérjék megfelelő konstellációja szükséges a célsejtekben. Ennek a betegcsoportnak a pontos meghatározása génexpressziós vagy izolált plazmasejteken végzett $\mathrm{RT} / \mathrm{PCR}$-vizsgálatokkal volna lehetséges. Bár például DLBCL-ben alkalmazott prognosztikai szerepe miatt a Bcl-2-expresszió meghatározható lenne, ahogy ezt a Bellini-tanulmány is mutatta, ennek egyedüli vizsgálata Bcl-xl- és Mcl-1-expresszió meghatározása nélkül pontatlan, és nem jósolja meg biztonsággal a terápiára jó választ adó betegeket. Az FDA döntésének megfelelően ezért praktikus és egyszerü a klinikumban általában rendelkezésre álló citogenetikai adatok alapján a $\mathrm{t}(11 ; 14)$ transzlokált betegek kiválasztása. Érdemes azonban azt is megjegyezni, hogy az 1q21-amplifikáció az Mcl-1-szint növekedésével járhat, ezért azok a betegek, akik $\mathrm{t}(11 ; 14)$ mellett 1q21-amplifikációval is rendelkeznek, várhatóan kevésbé jól fognak reagálni venetoclaxra.

A $\mathrm{t}(11 ; 14)$ betegcsoport a frissen diagnosztizált myelomások kb. 15-20\%-át alkotják, ismert viszont, hogy két, a plazmasejt dyscrasiák spektrumának ellenkező végleteit képviselő kórkép, az AL amyloidosis és a plazmasejtes leukaemia $(\mathrm{PCL})$ esetében a $\mathrm{t}(11 ; 14)$ transzlokált betegek aránya az 50\%-ot is elérheti [15-17]. Az előző esetében nem ritka a modern myelomakezelésekre adott renyhe válasz, márpedig itt esszenciális a fehérjetermelés minél nagyobb csökkenése, hiszen csak így van lehetőség a szervkárosodások visszafordítására. Több publikáció vizsgálja a venetoclax hatásosságát amyloidosisban [18-20], különösen érdekes a nagyon rövid kezelés utáni tartós hatás megfigyelése két beteg esetén [21]. PCL esetében nagyon gyakori a terápiarefrakteritás, és a kimenetel szinte mindig hónapokon belül fatális [22]. Venetoclaxkezeléssel egyelőre csak biztató esetriportok jelentek meg [23-25]. 


\section{Gyakorlati megfontolások}

A venetoclax leggyakoribb mellékhatásai a klinikai vizsgálatokban és esetleírásokban gastrointestinalis panaszok, általában 1-2 fokozatú hányinger, illetve hasmenés voltak $[18,19]$. A súlyosabb mellékhatások közül a neutropénia és infekciók fordultak elő gyakran (a neutropéniás lázat is beleértve), a kezelés alatt vérképkontroll, és szükség szerint G-CSF, esetenként transzfúzió adása válhat emiatt szükségessé, valamint megfontolandó antimikrobás profilaxis alkalmazása is. Különös odafigyelést igényelnek a gyakran alkalmazott antimikrobás gyógyszerekkel való interakciók: CYP3A enziminduktorok a venetoclax szérumszintjét megsokszorozhatják, például clarithromycin szedése mellett a venetoclaxdózis harmadára-negyedére csökkentendő. Ezt a mellékhatást a magunk javára is fordíthatjuk, ha például a venetoclaxot gastrointestinalis panaszok miatt nem tudja valaki a megfelelő dózisban szedni.

\section{Esetismertetés}

51 éves nőbetegünknél 2019 szeptemberében csontfájdalmak hátterében igazolódott ISS 1 stádiumú, kiterjedt csontrendszeri érintettséggel, jelentős könnyúlánc-emelkedéssel járó myeloma multiplex. VTD-kezelést kezdtünk, azonban két hét kezelést követően a könnyüláncszint a várt javulás helyett másfélszeresére nőtt, illetve mással nem magyarázható veseelégtelenség alakult ki (3. ábra). A venetoclaxkezelés szempontjából kedvező $\mathrm{t}(11 ; 14)$ transzlokációra tekintettel NEAK támogatással és OGYÉI off label engedéllyel venetoclaxot kezdtünk, amelynek hatására a könnyüláncértékek prompt javulni kezdtek. Teljes válasz elérését követően 2020 elején autológ őssejtátültetés történt. A beteg jelenleg lenalidomid fenntartás mellett a vizsgálható szintig minimális reziduális betegségtől mentes. Mellékhatás nem jelentkezett.

\section{Jövőbeli klinikai vizsgálatok}

Ezeknek az eredményeknek az ismeretében az FDA engedélyezte a venetoclax további vizsgálatát a t $(11 ; 14)$ csoportban: a folyamatban levő CANOVA klinikai vizsgálat (NCT03539744) lenalidomid-refrakter relabált/refrakter $\mathrm{t}(11 ; 14)$ myelomás betegek bevonásával a venetoclaxdexamethason kombináció hatásosságát vizsgálja pomalidomid-dexamethason kombinációval szemben. Az M15538-vizsgálat pedig a carfilzomib-venetoclax-dexamethason kombinációt teszteli egy relapszus után $\mathrm{t}(11 ; 14)$ esetekben, de folynak AL amyloidosisban is klinikai vizsgálatok.

Tekintve a gyógyszer extrém hatásosságát a $\mathrm{t}(11 ; 14)$ csoportban, csábító a korábbi alkalmazás, azonban az ezt támogató adatok egyelőre nem állnak rendelkezésre.

\section{Összefoglalás}

A venetoclaxterápia több hematológiai malignitás esetén hatásosnak és biztonságosnak bizonyult, azonban jelenlegi tudásunk alapján myeloma multiplexes betegek esetében - megfelelő és elérhető RT/PCR-tesztek hiányában a venetoclaxterápia csak $\mathrm{t}(11 ; 14)$ transzlokációval rendelkező betegek számára ajánlható. Jó kombinációs partnerek lehetnek a proteaszómainhibitorok. A fentebb vázolt ellentmondó study eredmények miatt egyelőre sikeres NEAK kérvények föleg olyan esetekben születtek, ahol a hagyományos eszköztár már kimerült. Minden jel arra utal azonban, hogy legalábbis a t $(11 ; 14)$ betegeknél a venetoclax alkalmazása hatásos és biztonságos alternatívát jelenthet, és a személyre szabott terápia felé való fej-

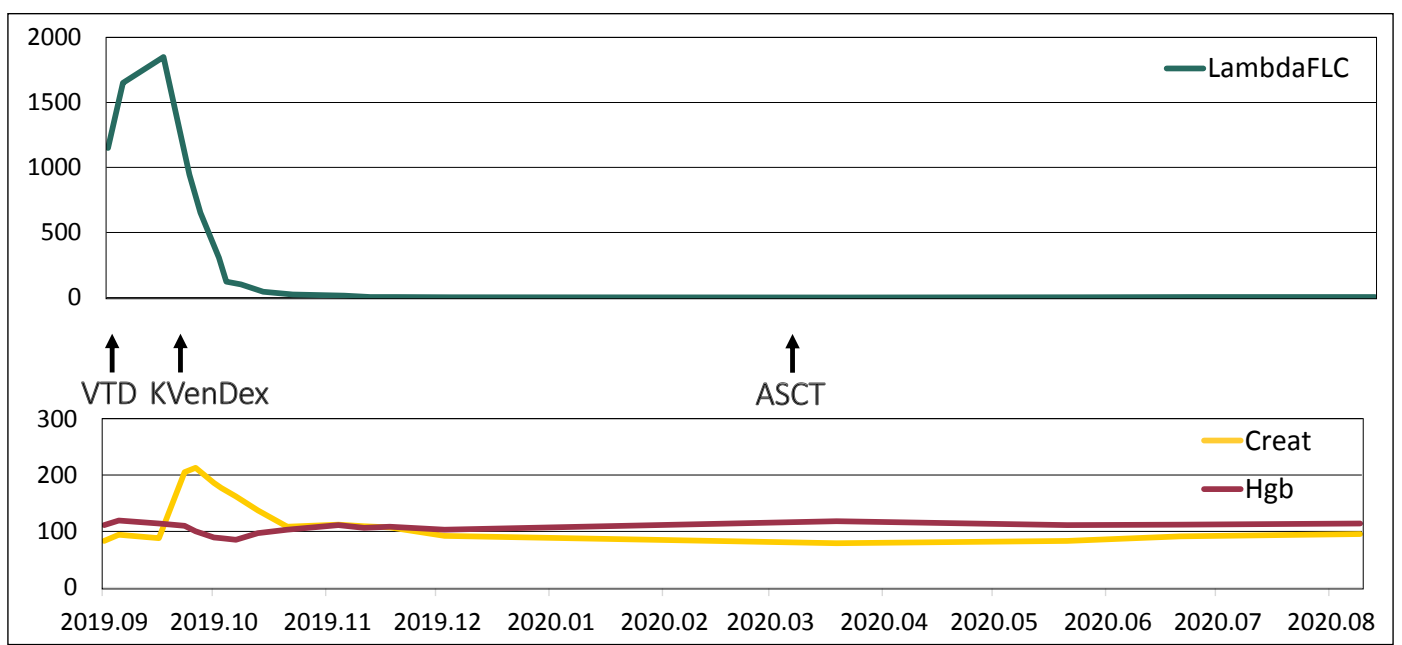

3. ábra. Könnyüláncértékek, hemoglobin- és kreatininszint alakulása betegünk kezelése során. Az első vonalbeli kezelés mellett progrediáló beteg prompt válasza carfilzomib-venetoclax-dexamethason kombinációra (ASCT - autológ őssejtátültetés; KvenDex - carfilzomib-venetoclax-dexamethason; lambdaFLC - lambda könnyűláncérték; VTD - bortezomib-thalidomid-dexamethason) 
lődés első lépcsőfoka lehet akár korábbi vonalban alkalmazva is.

Nyilatkozat: A közlemény más folyóiratban korábban nem jelent meg, máshová beküldésre nem került. A levelező szerző nyilatkozik arról, hogy a szerzői útmutatót elolvasta.

Érdekeltségek: A szerzőknek nincsenek érdekeltségeik. Anyagi támogatás: A közlemény megírása anyagi támogatásban nem részesült.

Szerzői munkamegosztás: Minden szerző részt vett a szöveg megfogalmazásában, és jóváhagyta a végső verziót.

\section{Irodalom}

[1] Meister S, Schubert U, Neubert K, Herrmann K, Burger R, Gramatzki M, et al. Extensive Immunoglobulin Production Sensitizes Myeloma Cells for Proteasome Inhibition. Cancer Research 2007; 67: 1783-1792.

[2] Nikesitch N, Ling SCW. Molecular mechanisms in multiple myeloma drug resistance. Journal of Clinical Pathology 2015; 69: $97-$ 101.

[3] Obeng EA, Carlson LM, Gutman DM, Harrington WJ, Lee KP, Boise LH. Proteasome inhibitors induce a terminal unfolded protein response in multiple myeloma cells. Blood 2006; 107: 49074916.

[4] Nikesitch N, Lee JM, Ling S, Roberts TL. Endoplasmic reticulum stress in the development of multiple myeloma and drug resistance. Clinical \& Translational Immunology 2018; 7(1): e1007.

[5] Xu C. Endoplasmic reticulum stress: cell life and death decisions. Journal of Clinical Investigation 2005; 115: 2656-2664.

[6] Touzeau C, Dousset C, Gouill SL, Sampath D, Leverson JD, Souers AJ, et al. The Bcl-2 specific BH3 mimetic ABT-199: a promising targeted therapy for $\mathrm{t}(11 ; 14)$ multiple myeloma. Leukemia 2013; 28: 210-212.

[7] Kumar S, Kaufman JL, Gasparetto C, Mikhael J, Vij R, Pegourie $\mathrm{B}$, et al. Efficacy of venetoclax as targeted therapy for relapsed/ refractory $\mathrm{t}(11 ; 14)$ multiple myeloma. Blood 2017; 130: 24012409.

[8] Moreau P, Chanan-Khan A, Roberts AW, Agarwal AB, Facon T, Kumar S, et al. Promising efficacy and acceptable safety of venetoclax plus bortezomib and dexamethasone in relapsed/refractory MM. Blood 2017; 130: 2392-2400.

[9] US Food and Drug Administration. FDA Warns about the risks associated with the investigational use of Venclexta in multiple myeloma [news release]. US Food and Drug Administration website. Published March 21, 2019

[10] Kumar S, Rajkumar SV. Surrogate endpoints in randomised controlled trials: a reality check. The Lancet $2019 ; 394: 281-283$.

[11] AbbVie Announces US FDA Lifts Partial Clinical Hold on Phase 3 Study of Venetoclax in Patients with Multiple Myeloma Positive for the $\mathrm{t}(11 ; 14)$ Genetic Abnormality. AbbVie News Center 2019 [cited 2020 Dec 19]. https://news.abbvie.com/news/pressreleases/abbvie-announces-us-fda-lifts-partial-clinical-hold-on- phase-3-study-venetoclax-in-patients-with-multiple-myeloma-positive-for-t1114-genetic-abnormality.htm

[12] Boccon-Gibod C, Talbot A, Bras FL, Frenzel L, Royer B, Harel S, et al. Carfilzomib, venetoclax and dexamethasone for relapsed/ refractory multiple myeloma. British Journal of Haematology 2020; 189(3): e73-e76.

[13] Costa LJ, Stadtmauer EA, Morgan GJ, Monohan GP, Kovacsovics $\mathrm{T}$, Burwick N, et al. Phase 2 study of venetoclax plus carfilzomib and dexamethasone in patients with relapsed/refractory multiple myeloma. Journal of Clinical Oncology 2018; 36: 8004.

[14] Rahbari KJ, Nosrati JD, Spektor TM, Berenson JR. Venetoclax in combination with bortezomib, dexamethasone, and daratumum$\mathrm{ab}$ for multiple myeloma. Clinical Lymphoma Myeloma and Leukemia 2018; 18(9): e339-e343.

[15] Muchtar E, Dispenzieri A, Kumar SK, Ketterling RP, Dingli D, Lacy MQ, et al. Interphase fluorescence in situ hybridization in untreated $\mathrm{AL}$ amyloidosis has an independent prognostic impact by abnormality type and treatment category. Leukemia 2016; 31 : 1562-1569.

[16] Hayman SR, Bailey RJ, Jalal SM, Ahmann GJ, Dispenzieri A, Gertz MA, et al. Translocations involving the immunoglobulin heavy-chain locus are possible early genetic events in patients with primary systemic amyloidosis. Blood 2001; 98: 2266-2268.

[17] Tiedemann RE, Gonzalez-Paz N, Kyle RA, Santana-Davila R, Price-Troska T, Wier SAV, et al. Genetic aberrations and survival in plasma cell leukemia. Leukemia 2008; 22: 1044-1052.

[18] Sidiqi MH, Saleh ASA, Leung N, Jevremovic D, Aljama MA, Gonsalves WI, et al. Venetoclax for the treatment of translocation $(11 ; 14)$ AL amyloidosis. Blood Cancer Journal 2020; 10(5): 55.

[19] Bras FL, Dupuis J, Lemonnier F, Oghina S, Bodez D, Ladaique A, et al. Venetoclax induces sustained complete responses in refractory/relapsed patients with cardiac AL amyloidosis. Journal of Clinical Oncology 2019; 37(15): DOI: 10.1200/JCO.2019.37.15_ suppl.e19538

[20] Leung N, Thomé SD, Dispenzieri A. Venetoclax induced a complete response in a patient with immunoglobulin light chain amyloidosis plateaued on cyclophosphamide, bortezomib and dexamethasone. Haematologica 2018; 103: e135-e137.

[21] Premkumar V, Comenzo RL, Lentzsch S. Preliminary evidence of efficacy of venetoclax in relapsed and refractory AL amyloidosis. Clinical Lymphoma Myeloma and Leukemia 2019; 19(10): 686688.

[22] Usmani SZ, Nair B, Qu P, Hansen E, Zhang Q, Petty N, et al. Primary plasma cell leukemia: clinical and laboratory presentation, gene-expression profiling and clinical outcome with Total Therapy protocols. Leukemia 2012; 26: 2398-2405.

[23] Nalghranyan S, Singh AP, Schinke C. The combination of venetoclax, daratumumab and dexamethasone for the treatment of refractory primary plasma cell leukemia. American Journal of Hematology. 2019; 95. https://doi.org/10.1002/ajh.25676

[24] Jelinek T, Mihalyova J, Kascak M, Duras J, Popkova T, Benkova $\mathrm{K}$, et al. Single-agent venetoclax induces MRD-negative response in relapsed primary plasma cell leukemia with $\mathrm{t}(11 ; 14)$. American Journal of Hematology 2018; 94. https://doi.org/10.1002/ ajh. 25331

[25] Gonsalves WI, Buadi FK, Kumar SK. Combination therapy incorporating Bcl-2 inhibition with Venetoclax for the treatment of refractory primary plasma cell leukemia with $\mathrm{t}(11 ; 14)$. European Journal of Haematology 2017; 100: 215-217.

A cikk a Creative Commons Attribution 4.0 International License (https://creativecommons.org/licenses/by/4.0/) feltételei szerint publikált Open Access közlemény, melynek szellemében a cikk bármilyen médiumban szabadon felhasználható, megosztható és újraközölhető, feltéve, hogy az eredeti szerző és a közlés helye, illetve a CC License linkje és az esetlegesen végrehajtott módosítások feltüntetésre kerülnek. (SID_1) 